\title{
Consultation-liaison psychiatry in Japan: a nationwide retrospective observational study
}

Daisuke Shinjo ${ }^{1,2}$, Hisateru Tachimori, ${ }^{3,4}$, Keiko Maruyama-Sakurai ${ }^{3,4}$, Kenji Fujimori $^{5}$, Norihiko Inoue ${ }^{1,2}$ and Kiyohide Fushimi $2^{*}$ (D)

\begin{abstract}
Background: Consultation-liaison psychiatry (CLP) — professional psychiatric care provided to coordinate with surgical or medical treatment of inpatients with psychiatric disorders - was included in universal health coverage in Japan in 2012. Despite evidence of benefits of CLP, basic data and geographic distribution information regarding CLP at the national level remain unclear. This study aimed to 1) identify the geographic disparity of CLP in Japan and 2) investigate the association between number of consultations per CLP patient and region.

Methods: We retrospectively analyzed anonymized data retrieved from the Japanese administrative inpatient database regarding inpatients who were provided CLP between April 2012 and March 2017. Demographic characteristics were summarized and geographic disparity by prefecture was visualized for fiscal years 2012 and 2016; we also summarized the data according to region. Multivariate linear regression analysis was used to investigate association between the number of consultations per CLP patient and region after adjusting for covariates.

Results: Data from a total of 46,171 patients who received 138,866 CLP services were included. Results revealed more patients aged $75-84$ years received CLPs than any other age group (29.7\%) and the overall male/female ratio was 53:47 in 2016. In 2012 and 2016, 24.2 and 30.7\% of CLP patients, respectively, were transferred to other hospitals; 9.7 and $8.8 \%$, respectively, discharged due to the death. CLP services were provided in 14 prefectures in 2012 and 33 by 2016; 14 prefectures had no available CLP services. After adjusting for covariates, Tohoku ( $\beta=-$ $0.220, p<0.034)$, Chugoku $(\beta=-0.160, p<0.026)$, and Shikoku $(\beta=-0.555, p<0.001$ ) had a significant negative correlation with the number of consultations per CLP patient compared with Hokkaido region (an adjusted $R$ square $(R 2)=0.274)$.

Conclusions: Our study clarified the characteristics of patients in Japan who received CLPs and the geographic disparity in CLP services. Although 5 years had passed since CLP was introduced, the results imply wide availability of CLP nationally. The analysis data provided may inform future policies to improve CLP services.
\end{abstract}

Keywords: Consultation-liaison psychiatry, Geographic disparity, Administrative database, DPC, Japan

\footnotetext{
* Correspondence: kfushimi.hci@tmd.ac.jp

${ }^{2}$ Department of Health Policy and Informatics, Tokyo Medical and Dental University Graduate School, 1-5-45 Yushima, Bunkyo-ku, Tokyo 1138519, Japan

Full list of author information is available at the end of the article
}

(C) The Author(s). 2021 Open Access This article is licensed under a Creative Commons Attribution 4.0 International License, which permits use, sharing, adaptation, distribution and reproduction in any medium or format, as long as you give appropriate credit to the original author(s) and the source, provide a link to the Creative Commons licence, and indicate if changes were made. The images or other third party material in this article are included in the article's Creative Commons licence, unless indicated otherwise in a credit line to the material. If material is not included in the article's Creative Commons licence and your intended use is not permitted by statutory regulation or exceeds the permitted use, you will need to obtain permission directly from the copyright holder. To view a copy of this licence, visit http://creativecommons.org/licenses/by/4.0/. The Creative Commons Public Domain Dedication waiver (http://creativecommons.org/publicdomain/zero/1.0/) applies to the data made available in this article, unless otherwise stated in a credit line to the data. 


\section{Background}

Across OECD (Organization for Economic Cooperation and Development) member countries, on average, the share of the population aged 65 and over is projected to continue increasing in the coming decades, which will likely lead to greater demand for labor-intensive longterm healthcare [1]. As societies are progressively aging and healthcare technology is advancing, the number of medical or surgical patients with psychiatric comorbidities is increasing. This increase is due, in part, to the higher risk of mental disorders in elderly populations than other populations [2]. Additionally, hospital inpatients with any psychiatric comorbidity are more likely to utilize health care resources (i.e. longer hospital stays) than those with medical conditions only [3-6]. Indeed, psychological comorbidities commonly exacerbate physical illnessassociated symptoms, contributing to increased healthcare utilization and costs. Psychiatric comorbidity is even associated with increasing excess mortality $[7,8]$ and the number of patient rehospitalizations [9].

Consultation-liaison psychiatry (CLP) is the discipline of providing professional psychiatric care to inpatients who are primarily admitted for medical or surgical (somatic) reasons in whom comorbid psychiatric symptoms are revealed after hospital admission. From the reports by Lipowski [10-12], the scope, organization, and strategic aspects of CLP in general hospitals/wards have developed worldwide. Previous studies show that CLP reduces medical complications, length of stay, and number of hospitalizations via early referral for psychiatric consultations, treatment of psychiatric presentation on medical and surgical units, and facilitating access to appropriate psychiatric treatment post-discharge [13-17].

In terms of implementing CLP services and in the application of CLP guidelines, there are several differences among countries [18]. In Japan, the concept of CLP was introduced over 50 years ago, but was in preliminary stages of development for many years [18]; CLP was included in the health insurance standards in 2012, thus it was finally covered by universal health coverage. This inclusion was due to the growing needs for psychiatric care to patients with psychiatric disorders such as delirium in acute-care hospitals. Also, this inclusion was partly based on both the request from associations of healthcare providers and political motivation for supporting interprofessional team collaboration for improving quality of care and patients' quality of life.

In short, CLP care is to be provided by a multidisciplinary team (i.e. psychiatrists, nurses, pharmacists, and other professions) to improve quality of care and treatment in medical and surgical patients who may benefit from coordinated, multi-discipline care. The CLP team organized treatment plan based on the CLP guidance published by the Japanese Society of General Hospital Psychiatry [19].
On CLP, psychiatrists and psychiatric-trained staff may get involved from the beginning and contribute to prevention, earlier detection, and intervention for the psychological distress and psychiatric symptoms [20]. CLP may also provide education to the staff team, provide direct care to the patients' family, and adjust psychiatric care after discharge. The details of CLP services in Japan were described elsewhere [18]. CLP would enable us to find such patients and provide psychiatric care in their early stage, which contribute to reducing their psychiatric symptoms and assisting early discharge.

Previous studies have reported several aspects of CLP services in Japanese settings, such as in cancer cohorts, psychiatric diagnoses, and treating depression [17, 21, 22]. However, neither basic data nor geographic disparity pertaining to the provision of CLP services in the national level remains unclear. It is essential to capture clinical features of patients who received CLP services and CLP distribution for achieving efficient CLP care under the limited healthcare resources available to the rapidly aging society. Use of Nationwide Database is one of the attractive approaches to address this issue.

The aim of this study was to use information from the Japanese Administrative Database to describe the clinical features of current CLP settings and to reveal the geographic distribution of CLP services in Japan. This study was also designed to investigate the association between the number of consultations per CLP patient and region after adjusting for covariates.

\section{Methods}

\section{Data source}

This was a retrospective, observational study that used data from the Japanese Administrative Database; the Diagnosis Procedure Combination (DPC) per-diem payment system (DPC/PDPS) (details of the DPC/PDPS have been described elsewhere) [23, 24]. Briefly, the DPC/PDPS is a case-mix patient classification system that is linked to payments at acute-care and mixed-care hospitals in Japan. By 2016, the DPC/PDPS-based hospital reimbursement system had been adopted by more than 1600 hospitals, which accounted for more than half of the total 894,000 hospital beds nationwide. The DPC (Administrative) database, consists of routinely collected electronic data, is different from registry database where patients who meet criteria are registered according to the study purpose by the healthcare professional.

Anonymous clinical and administrative claims data were collected annually for patients from the participating hospitals. Clinical data consists of baseline patient information, diagnosis (based on ICD-10), and detailed medical information such as all major or minor procedures, medication, and device use. The database also includes the purpose of admission, discharge destination, and outcome at 
the time of hospital discharge. Hospital information is also collected under the DPC/PDPS. We obtained population data according to prefectures from a national survey called Population Estimates [25]. Each region consists of several prefectures. The database did not include detailed clinical data regarding psychiatry.

This study was approved by the Institutional Review Board at the Tokyo Medical and Dental University and the National Center for Child Health and Development. The board waived off the requirement for patient informed consent because of the anonymous nature of the data. Data used in this study is not publicly available (for further information, see Declarations "Ethics approval and consent to participate").

\section{Participants and variables}

We identified patients who had received CLP (Japanese code: A230-4) between April 1, 2012, and March 31, 2017, from the DPC database. We excluded 224 patients with 397 CLP services from one hospital due to not having complete hospital information.

Data pertaining to individual-level characteristics were extracted. Individual variables included age, sex, admission status (planned, unplanned, or urgent), discharge settings, discharge outcome, and disease classification according to ICD-10. Age was categorized into six groups: $0-29,30-49$, 50-64, 65-74, 75-84, and 85+. Disease classification was categorized according to ICD-10 Chapter numbers from "I "(Certain infectious and parasitic diseases) to "XXII' (Codes for special purposes). Data regarding in-hospital psychotherapy were also obtained from the database. In-hospital psychiatry was recorded in the administrative database a maximum of three times per week due to the limitations of the payment system. In this study, in-hospital psychotherapy is defined as a Japanese medical service fee code I001, a psychological therapy for inpatients with psychiatric disorders, provided by the psychiatrists according to the assessment of the patients. Each psychotherapy session must last for more than 30 minutes as "I100 in-hospital psychotherapy," and claimed for a maximum of 3 times per week (depending on a patient's condition).

\section{Statistical analysis}

Continuous variables were summarized with the use of descriptive statistics (mean \pm standard deviation for values with normal distribution, and the median with interquartile range (IQR) for values with non-normal distribution), and categorical variables were summarized as frequencies and proportions. Chi-square test of independence with Cramer's V strength was used to investigate if there is a significant relationship between regions and other variables. An analysis of variance was used to determine whether there are any statistically significant differences between the means of regions. Post hoc analyses were performed using the Scheffé method or Fisher's Exact test. A forced entry multivariate linear regression analysis was conducted to determine if region was independently correlated with the number of consultations per CLP patient after adjusting for other variables. The variance inflation factor (VIF) was used for checking the degree of multicollinearity. All statistical analyses were performed using $\mathrm{R}$ statistical software, version 3.3.2 (R Foundation for Statistical Computing, Vienna, Austria), and data visualization were performed by Tableau Software version 2018.3 (Tableau software, Seattle, United States of America).

\section{Results}

\section{Patient and hospital characteristics}

A total of 46,171 patients who were provided CLP qualified based on the inclusion criteria. Table 1 shows the basic characteristics of those patients and hospitals. The age group who used the services the most included those patients aged 75-84 years $(29.7 \%$ in 2016). About half of all patients were female (47.2\% in 2016), and the proportion of patients whose CLP-related medical care was unplanned or urgent was $67.8 \%$ in 2016. Also in that year, 109 hospitals in Japan provided CLPs. The number of provided CLP services, patients who received CLP, and hospitals providing CLP increased almost three- to four-fold in between 2012, when CLP was introduced, and 2016 (428, 406, and 363\%, respectively). The frequency of CLP per patient did not change significantly during the study period. The coefficient of variation of the number of consultations per CLP patient remained relatively constant during our study period.

The characteristics of patients' discharge settings and outcomes as of discharge are also shown in Table 1. More than half of the patients were discharged and followed-up by outpatient services (53.3\% in 2016), while about nearly one-third of the patients were transferred to other hospitals $(30.7 \%$ in 2016$)$ and $5.1 \%$ of were transferred to welfare facilities in 2016. Overall, the inhospital mortality ratio for the patients who received CLP services was about 9\% (8.8\% in 2016).

Characteristics of disease classification by "most resource-consuming diagnosis," of study cohorts are summarized in Table 2. The highest proportion of disease classification was "neoplasm" (22.9\% in 2016), followed by "disease of circulatory system" (16.7\% in 2016), "injury, poisoning and certain other consequences of external causes" (13.7\% in 2016) and "other" classifications.

The provision of in-hospital psychotherapy in the study cohort was summarized in Appendix. About three-tenth of the patients did not have in-hospital psychotherapy (31.9\% in 2016), while about one-fifth of the patients had just one in-hospital psychotherapy (19.5\% in 2016). Almost half of the patients had several in- 
Table 1 Characteristics of patients and hospitals cohorts in the study (Patients $N=46,170$ )

\begin{tabular}{|c|c|c|c|c|c|c|c|c|}
\hline \multirow[t]{2}{*}{ Variables } & \multicolumn{5}{|l|}{ Fiscal year } & \multirow{2}{*}{$\begin{array}{l}\text { Proportion } \\
\text { (2012) }\end{array}$} & \multirow{2}{*}{$\begin{array}{l}\text { Proportion } \\
\text { (2016) }\end{array}$} & \multirow{2}{*}{$\begin{array}{l}\text { Rate of } \\
\text { increase } \\
(2016 \\
\text { vs. } \\
2012)\end{array}$} \\
\hline & 2012 & 2013 & 2014 & 2015 & 2016 & & & \\
\hline Patients & 3989 & 5352 & 8358 & 11,408 & 17,064 & & & $428 \%$ \\
\hline \multicolumn{9}{|l|}{ Consultation-Liaison Psychiatry } \\
\hline Overall & 11,800 & 17,807 & 26,283 & 35,084 & 47,912 & & & $406 \%$ \\
\hline Per patient (mean, SD) & $2.96(2.73)$ & $3.33(3.64)$ & $3.14(3.14)$ & $3.08(3.15)$ & $2.81(2.75)$ & & & - \\
\hline Per patient (median, interquartile range) & $2[1-4]$ & $2[1-4]$ & $2[1-4]$ & $2[1-4]$ & $2[1-3]$ & & & - \\
\hline Per patient (range) & $1-29$ & $1-67$ & $1-40$ & $1-48$ & $1-80$ & & & \\
\hline Coefficient of variation & 0.92 & 1.10 & 1.00 & 1.03 & 0.98 & & & - \\
\hline Hospitals & 30 & 34 & 42 & 51 & 109 & & & $363 \%$ \\
\hline \multicolumn{9}{|l|}{ Age group } \\
\hline $0-29$ & 164 & 231 & 327 & 479 & 662 & $4.1 \%$ & $3.9 \%$ & \\
\hline $30-49$ & 542 & 796 & 1193 & 1299 & 2019 & $13.6 \%$ & $11.8 \%$ & \\
\hline $50-64$ & 721 & 1013 & 1431 & 1795 & 2556 & $18.1 \%$ & $15.0 \%$ & \\
\hline $65-74$ & 778 & 1127 & 1746 & 2536 & 3527 & $19.5 \%$ & $20.7 \%$ & \\
\hline $75-84$ & 1168 & 1391 & 2386 & 3279 & 5061 & $29.3 \%$ & $29.7 \%$ & \\
\hline $85+$ & 616 & 794 & 1275 & 2020 & 3239 & $15.4 \%$ & $19.0 \%$ & \\
\hline \multicolumn{9}{|l|}{ Sex } \\
\hline Male & 2026 & 2651 & 4290 & 6023 & 9015 & $50.8 \%$ & $52.8 \%$ & \\
\hline Female & 1963 & 2701 & 4068 & 5385 & 8049 & $49.2 \%$ & $47.2 \%$ & \\
\hline \multicolumn{9}{|l|}{ Admission setting } \\
\hline Planned & 1451 & 1887 & 3023 & 4051 & 5497 & $36.4 \%$ & $32.2 \%$ & \\
\hline Unplanned or Urgent & 2538 & 3465 & 5335 & 7357 & 11,567 & $63.6 \%$ & $67.8 \%$ & \\
\hline \multicolumn{9}{|l|}{ Discharge setting } \\
\hline Outpatients follow up & 2413 & 3209 & 4730 & 6255 & 9100 & $60.5 \%$ & $53.3 \%$ & \\
\hline Transfer to other hospitals & 966 & 1311 & 2231 & 3334 & 5238 & $24.2 \%$ & $30.7 \%$ & \\
\hline Transfer to other welfare facilities & 139 & 173 & 486 & 611 & 876 & $3.5 \%$ & $5.1 \%$ & \\
\hline Others & 471 & 659 & 911 & 1208 & 1850 & $11.8 \%$ & $10.8 \%$ & \\
\hline \multicolumn{9}{|l|}{ Discharge outcome } \\
\hline Treated & 3177 & 4331 & 6709 & 9370 & 14,025 & $79.6 \%$ & $82.2 \%$ & \\
\hline Unchanged or worsened & 358 & 333 & 671 & 789 & 1124 & $9.0 \%$ & $6.6 \%$ & \\
\hline Death & 385 & 539 & 783 & 985 & 1505 & $9.7 \%$ & $8.8 \%$ & \\
\hline Other & 69 & 149 & 195 & 264 & 410 & $1.7 \%$ & $2.4 \%$ & \\
\hline \multicolumn{9}{|l|}{ Length of stay } \\
\hline $2-17$ days & 989 & 1189 & 2294 & 3179 & 4754 & $24.8 \%$ & $27.9 \%$ & \\
\hline 18-30 days & 938 & 1269 & 1941 & 2724 & 4330 & $23.5 \%$ & $25.4 \%$ & \\
\hline $31-54$ days & 1038 & 1315 & 1952 & 2798 & 4211 & $26.0 \%$ & $24.7 \%$ & \\
\hline 55 days and over & 1024 & 1579 & 2171 & 2707 & 3769 & $25.7 \%$ & $22.1 \%$ & \\
\hline
\end{tabular}

Consultation-Liaison Psychiatry (CLP) services were recorded once a week regardless of multiple CLPs being providing in a week

hospital psychotherapy sessions, and $13.9 \%$ of the patients had more than six psychotherapy sessions in 2016.

The geographic distribution of CLP services in 2012 and 2016 are shown in Fig. 1. Among the 47 prefectures in Japan, CLPs were provided in 14 prefectures $(29.8 \%)$ at 30 hospitals in 2012. As of 2016, CLPs were provided in 33 prefectures $(70.2 \%)$ at 109 hospitals; 14 prefectures have never offered CLPs. Table 3 also shows descriptive statistics of CLPs by region. There was no hospital providing CLP services in the Shikoku area until 2014 (data 
Table 2 Disease classification of the study cohorts

\begin{tabular}{|c|c|c|c|c|c|c|c|}
\hline \multirow[t]{2}{*}{ Disease classification } & \multicolumn{5}{|c|}{ Fiscal year } & \multirow{2}{*}{$\begin{array}{l}\text { Proportion } \\
\text { of patients } \\
\text { (n) in } 2012\end{array}$} & \multirow{2}{*}{$\begin{array}{l}\text { Proportion } \\
\text { of patients } \\
\text { (n) in } 2016\end{array}$} \\
\hline & 2012 & 2013 & 2014 & 2015 & 2016 & & \\
\hline 1. Certain infectious and parasitic diseases & 146 & 187 & 345 & 377 & 580 & $3.7 \%$ & $3.4 \%$ \\
\hline 2. Neoplasms & 1083 & 1333 & 2036 & 2795 & 3906 & $27.1 \%$ & $22.9 \%$ \\
\hline $\begin{array}{l}\text { 3. Diseases of the blood and blood-forming organs and certain disorders involving } \\
\text { the immune mechanism }\end{array}$ & 70 & 97 & 131 & 166 & 226 & $1.8 \%$ & $1.3 \%$ \\
\hline 4. Endocrine, nutritional, and metabolic diseases & 164 & 232 & 320 & 385 & 596 & $4.1 \%$ & $3.5 \%$ \\
\hline 5. Mental and behavioral disorders & 65 & 107 & 172 & 181 & 328 & $1.6 \%$ & $1.9 \%$ \\
\hline 6. Diseases of the nervous system & 141 & 189 & 325 & 393 & 609 & $3.5 \%$ & $3.6 \%$ \\
\hline 7. Diseases of the eye and adnexa & 25 & 26 & 41 & 38 & 71 & $0.6 \%$ & $0.4 \%$ \\
\hline 8. Diseases of the ear and mastoid process & 7 & 9 & 36 & 40 & 39 & $0.2 \%$ & $0.2 \%$ \\
\hline 9. Diseases of the circulatory system & 614 & 788 & 1264 & 1870 & 2851 & $15.4 \%$ & $16.7 \%$ \\
\hline 10. Diseases of the respiratory system & 365 & 493 & 723 & 912 & 1542 & $9.2 \%$ & $9.0 \%$ \\
\hline 11. Diseases of the digestive system & 352 & 499 & 782 & 1046 & 1666 & $8.8 \%$ & $9.8 \%$ \\
\hline 12. Diseases of the skin and subcutaneous tissue & 59 & 98 & 173 & 194 & 261 & $1.5 \%$ & $1.5 \%$ \\
\hline 13. Diseases of the musculoskeletal system and connective tissue & 171 & 302 & 517 & 727 & 1085 & $4.3 \%$ & $6.4 \%$ \\
\hline 14. Diseases of the genitourinary system & 168 & 241 & 371 & 552 & 711 & $4.2 \%$ & $4.2 \%$ \\
\hline 15. Pregnancy, childbirth, and the puerperium & 52 & 67 & 120 & 131 & 213 & $1.3 \%$ & $1.2 \%$ \\
\hline 17. Congenital malformations, deformations, and chromosomal abnormalities & 10 & 13 & 21 & 31 & 40 & $0.3 \%$ & $0.2 \%$ \\
\hline $\begin{array}{l}\text { 18. Symptoms, signs, and abnormal clinical and laboratory findings, not elsewhere } \\
\text { classified }\end{array}$ & 1 & 2 & 3 & 8 & 6 & $0.0 \%$ & $0.0 \%$ \\
\hline 19. Injury, poisoning, and certain other consequences of external causes & 496 & 669 & 978 & 1562 & 2333 & $12.4 \%$ & $13.7 \%$ \\
\hline 21. Factors influencing health status and contact with health services & 0 & 0 & 0 & 0 & 1 & $0.0 \%$ & $0.0 \%$ \\
\hline
\end{tabular}

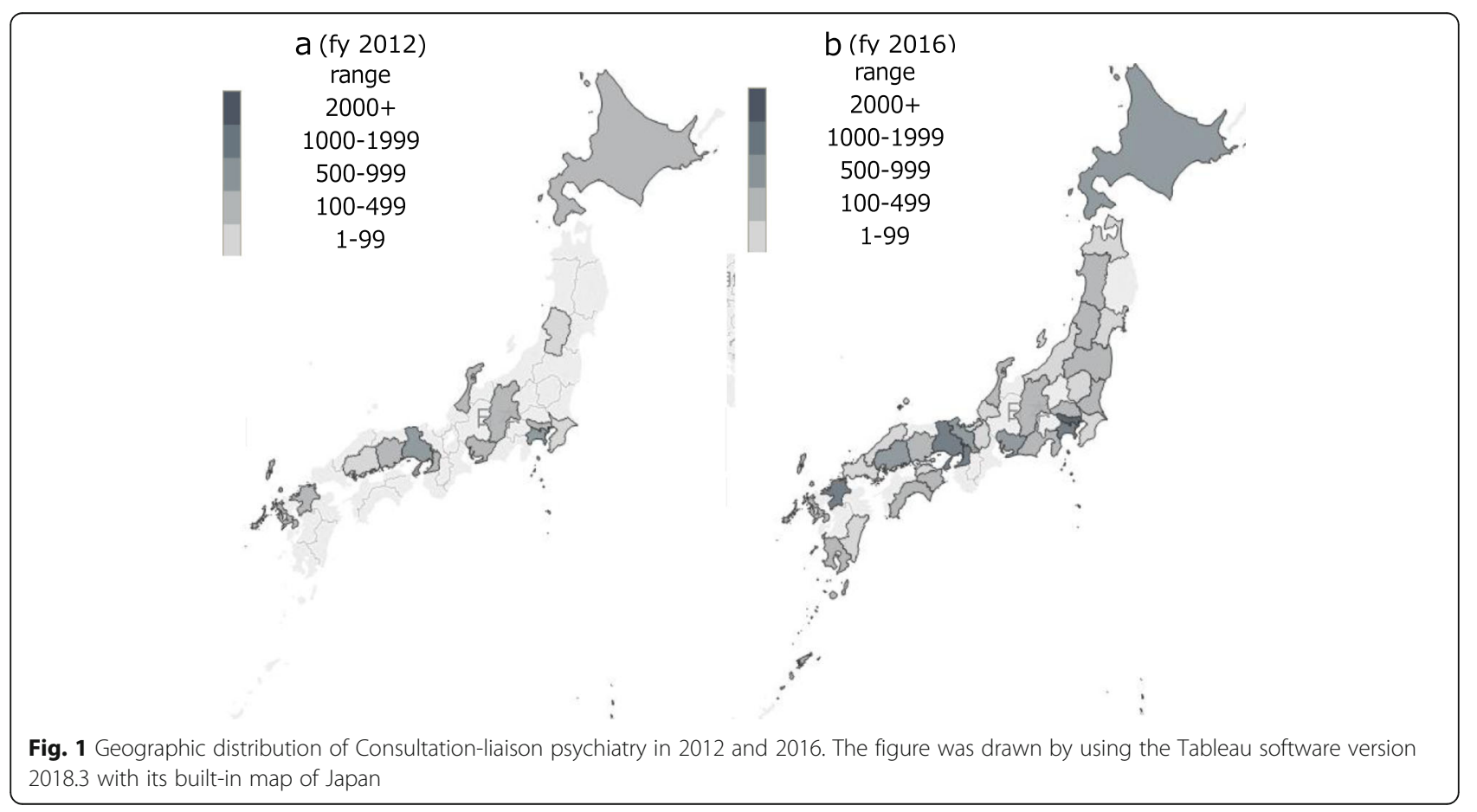


Table 3 Cross tabulation for number of patients, provided CLP services, hospitals, and population data by region

\begin{tabular}{|c|c|c|c|c|c|c|c|c|c|c|c|c|c|c|}
\hline \multirow[b]{3}{*}{ Region } & \multirow{2}{*}{\multicolumn{2}{|c|}{$\begin{array}{l}\text { Number of } \\
\text { patients } \\
\text { Fiscal year }\end{array}$}} & \multirow{2}{*}{\multicolumn{2}{|c|}{$\begin{array}{l}\text { Number of } \\
\text { CLP } \\
\text { performed }\end{array}$}} & \multirow{2}{*}{\multicolumn{2}{|c|}{$\begin{array}{l}\text { Number of } \\
\text { hospitals } \\
\text { providing } \\
\text { CLP } \\
\text { Fiscal year }\end{array}$}} & \multirow{3}{*}{$\begin{array}{l}\text { Number of DPC } \\
\text { hospitals } \\
\text { Fiscal year } \\
2016\end{array}$} & \multicolumn{6}{|c|}{ Regional data } & \multirow{3}{*}{$\begin{array}{l}\text { CLP } \\
\text { services } \\
\text { per } \\
\text { population } \\
2016\end{array}$} \\
\hline & & & & & & & & \multicolumn{3}{|c|}{ Number of prefectures } & \multicolumn{3}{|c|}{ populations (2016) * } & \\
\hline & 2012 & 2016 & 2012 & 2016 & 2012 & 2016 & & overall & $\begin{array}{l}\text { CLP in } \\
2012\end{array}$ & $\begin{array}{l}\text { CLP in } \\
2016\end{array}$ & overall & $65+$ & $\begin{array}{l}\text { aging } \\
\text { ratio }\end{array}$ & \\
\hline Hokkaido & 202 & 939 & 673 & 2772 & 1 & 4 & 89 & 1 & 1 & 1 & 5352 & 1602 & $29.9 \%$ & 0.52 \\
\hline Tohoku & 35 & 641 & 115 & 1879 & 1 & 10 & 109 & 6 & 1 & 5 & 8915 & 2674 & $30.0 \%$ & 0.21 \\
\hline Kanto & 1008 & 6138 & 3016 & $\begin{array}{l}18 \\
309\end{array}$ & 11 & 35 & 427 & 7 & 3 & 6 & 43,132 & $\begin{array}{l}10 \\
748\end{array}$ & $24.9 \%$ & 0.42 \\
\hline Chubu & 743 & 1512 & 2209 & 4175 & 4 & 19 & 274 & 9 & 3 & 6 & 21,415 & 5922 & $27.7 \%$ & 0.19 \\
\hline Kinki & 1100 & 4561 & 3185 & $\begin{array}{l}12 \\
038\end{array}$ & 8 & 22 & 325 & 7 & 2 & 4 & 22,489 & 6203 & $27.6 \%$ & 0.54 \\
\hline Chugoku & 268 & 774 & 900 & 2007 & 3 & 6 & 116 & 5 & 2 & 4 & 7406 & 2218 & $29.9 \%$ & 0.27 \\
\hline Shikoku & & 411 & & 925 & & 4 & 64 & 4 & 0 & 3 & 3818 & 1209 & $31.7 \%$ & 0.24 \\
\hline $\begin{array}{l}\text { Kyushu- } \\
\text { Okinawa }\end{array}$ & 633 & 2088 & 1702 & 5807 & 2 & 9 & 262 & 8 & 2 & 4 & 14,405 & 4014 & $27.9 \%$ & 0.40 \\
\hline Total & 3989 & $\begin{array}{l}17 \\
064\end{array}$ & $\begin{array}{l}11 \\
800\end{array}$ & $\begin{array}{l}47 \\
912\end{array}$ & 30 & 109 & 1666 & 47 & 14 & 33 & $\begin{array}{l}126 \\
933\end{array}$ & $\begin{array}{l}34 \\
591\end{array}$ & $27.3 \%$ & 0.38 \\
\hline
\end{tabular}

CLP Consultation-Liaison Psychiatry, DPC Diagnosis Procedure Combination; ${ }^{*}$ unit: thousands

not shown), while more than one-third of the CLP services provided in 2016 were in the Kanto area. The provided CLP services per population ratio showed wide variation even in the regional area level (range: 0.190.54 CLP services per thousand population).

The result of the test of independence and ANOVA (Fiscal year 2016) is shown in Tables 4 and 5 (Post hoc analysis was presented in Additional file 1). The result revealed there is an association between regions and other variables; age group $(p<0.001$, Cramer's $V=0.097)$, sex $(p=0.009$, Cramer's $\mathrm{V}=0.032)$, admission setting $(\mathrm{p}<$ 0.001 , Cramer's $V=0.163)$, discharge setting $(p<0.001$, Cramer's V $=0.127)$, discharge outcome $(p<0.001$, Cramer's V $=0.077)$, disease classification $(p<0.001$, Cramer's $\mathrm{V}=0.078)$, length of stay $(p<0.001$, Cramer's $V=0.044)$ and number of CLP services per patient $(p<0.001)$. Number of patients aged over 75 was the highest in Tohoku (63.1\%) and lowest in Kyusyu-Okinawa (38.9\%). The proportion of female patients was slightly lower than that of male patients. In most case, the admission setting was unplanned (52.9 to 84.4\%). Shikoku (56.4\%) and KyusyuOkinawa $(55.0 \%)$ were characterized by a higher proportion of patients who transferred to other hospitals. The discharge outcome was mostly "treated" (78.5 to $90.8 \%$ ), followed by "death" (5.6 to 11.0\%). CLP per patient was highest in Kanto (mean $=2.98$ ).

Table 6 shows the results of a multiple regression analysis wherein the number of consultations per CLP patient was used as the dependent variable. Multivariate linear regression analysis revealed that Shikoku $(\beta=-0.024, p<$ $0.001)$, Chugoku $(\beta=-0.023, p<0.001)$, and Kyusyu-
Okinawa $(\beta=-0.030, p<0.001)$ had a significant negative correlation with the number of consultations per CLP patient compared with Hokkaido region, after adjusting for age group, sex, admission setting, disease classification, length of stay, and fiscal year. Adjusted R square (R2) of the model was 0.274 , which indicates that this model explains $27.4 \%$ of the variance in the dependent variable. No strong collinearity was observed among the explanatory variables (VIF $<2$ for each explanatory variable).

\section{Discussion}

The present retrospective study investigated the nationallevel CLP service in general hospitals in Japan, using a national inpatient database. The present study characterized (1) the key overview of patients who received CLP services and (2) the geographic disparity of these patients. To the best of our knowledge, this article is one of the first reports revealing CLP disparity. CLP would contribute to not only providing psychiatric care for patients admitted to medical general wards, but also promoting patients' smooth discharge through early detection and intervention for the psychological and psychiatric symptoms. CLP also helped to adjust psychiatric care after discharge, which may lead patients to be promoted appropriate adherence and be treated within the psychiatric communitycare networks that have a significant impact on the use of mental healthcare services [26]. In today's current health care climate of cost savings, limited allocation of resources, and expectations of demonstrations of the value of services and clinical productivity, it is important to clarify the current situation regarding CLP services to 
Table 4 Characteristics of patients by region (2016)

\begin{tabular}{|c|c|c|c|c|c|c|c|c|c|c|}
\hline Variables & Hokkaido & Tohoku & Kanto & Chubu & Kinki & Chugoku & Shikoku & $\begin{array}{l}\text { Kyushu- } \\
\text { Okinawa }\end{array}$ & $p$ value & $\begin{array}{l}\text { Cramer's } \\
\text { V }\end{array}$ \\
\hline N & 939 & 641 & 6138 & 1512 & 4561 & 774 & 411 & 2088 & & \\
\hline Age group (\%) & & & & & & & & & $<0.001$ & 0.097 \\
\hline $0-29$ & $42(4.5)$ & $12(1.9)$ & $291(4.7)$ & $41(2.7)$ & $128(2.8)$ & $16(2.1)$ & $5(1.2)$ & $127(6.1)$ & & \\
\hline $30-49$ & $116(12.4)$ & $45(7.0)$ & $873(14.2)$ & $149(9.9)$ & $417(9.1)$ & $76(9.8)$ & $37(9.0)$ & $306(14.7)$ & & \\
\hline $50-64$ & $159(16.9)$ & $77(12.0)$ & $\begin{array}{l}1070 \\
(17.4)\end{array}$ & $191(12.6)$ & $522(11.4)$ & $98(12.7)$ & $61(14.8)$ & $378(18.1)$ & & \\
\hline $65-74$ & $228(24.3)$ & $\begin{array}{l}103 \\
(16.1)\end{array}$ & $\begin{array}{l}1275 \\
(20.8)\end{array}$ & $274(18.1)$ & $942(20.7)$ & $153(19.8)$ & $87(21.2)$ & $465(22.3)$ & & \\
\hline $75-84$ & $283(30.1)$ & $\begin{array}{l}212 \\
(33.1)\end{array}$ & $\begin{array}{l}1724 \\
(28.1)\end{array}$ & $480(31.7)$ & $\begin{array}{l}1469 \\
(32.2)\end{array}$ & $260(33.6)$ & $\begin{array}{l}128 \\
(31.1)\end{array}$ & $505(24.2)$ & & \\
\hline $85+$ & $111(11.8)$ & $\begin{array}{l}192 \\
(30.0)\end{array}$ & $905(14.7)$ & $377(24.9)$ & $\begin{array}{l}1083 \\
(23.7)\end{array}$ & $171(22.1)$ & $93(22.6)$ & $307(14.7)$ & & \\
\hline Sex (\%) & & & & & & & & & 0.009 & 0.032 \\
\hline Male & $506(53.9)$ & $\begin{array}{l}329 \\
(51.3)\end{array}$ & $\begin{array}{l}3346 \\
(54.5)\end{array}$ & $784(51.9)$ & $\begin{array}{l}2327 \\
(51.0)\end{array}$ & $394(50.9)$ & $\begin{array}{l}234 \\
(56.9)\end{array}$ & $1095(52.4)$ & & \\
\hline Female & $433(46.1)$ & $\begin{array}{l}312 \\
(48.7)\end{array}$ & $\begin{array}{l}2792 \\
(45.5)\end{array}$ & $728(48.1)$ & $\begin{array}{l}2234 \\
(49.0)\end{array}$ & $380(49.1)$ & $\begin{array}{l}177 \\
(43.1)\end{array}$ & $993(47.6)$ & & \\
\hline Admission setting (\%) & & & & & & & & & $<0.001$ & 0.163 \\
\hline Planned & $442(47.1)$ & $\begin{array}{l}100 \\
(15.6)\end{array}$ & $\begin{array}{l}2157 \\
(35.1)\end{array}$ & $336(22.2)$ & $\begin{array}{l}1445 \\
(31.7)\end{array}$ & $253(32.7)$ & $66(16.1)$ & $698(33.4)$ & & \\
\hline Unplanned or Urgent & $497(52.9)$ & $\begin{array}{l}541 \\
(84.4)\end{array}$ & $\begin{array}{l}3981 \\
(64.9)\end{array}$ & $\begin{array}{l}1176 \\
(77.8)\end{array}$ & $\begin{array}{l}3116 \\
(68.3)\end{array}$ & $521(67.3)$ & $\begin{array}{l}345 \\
(83.9)\end{array}$ & $1390(66.6)$ & & \\
\hline Discharge setting (\%) & & & & & & & & & $<0.001$ & 0.127 \\
\hline Outpatients follow up & $600(63.9)$ & $\begin{array}{l}302 \\
(47.1)\end{array}$ & $\begin{array}{l}3648 \\
(59.4)\end{array}$ & $746(49.3)$ & $\begin{array}{l}2390 \\
(52.4)\end{array}$ & $363(46.9)$ & $\begin{array}{l}133 \\
(32.4)\end{array}$ & $918(44.0)$ & & \\
\hline Transfer to other hospitals & $248(26.4)$ & $\begin{array}{l}203 \\
(31.7)\end{array}$ & $\begin{array}{l}1586 \\
(25.8)\end{array}$ & $449(29.7)$ & $\begin{array}{l}1324 \\
(29.0)\end{array}$ & $278(35.9)$ & $\begin{array}{l}232 \\
(56.4)\end{array}$ & $918(44.0)$ & & \\
\hline Transfer to other welfare facilities & $15(1.6)$ & $61(9.5)$ & $247(4.0)$ & $137(9.1)$ & $277(6.1)$ & $33(4.3)$ & $22(5.4)$ & $84(4.0)$ & & \\
\hline Others & $76(8.1)$ & $75(11.7)$ & $657(10.7)$ & $180(11.9)$ & $570(12.5)$ & $100(12.9)$ & $24(5.8)$ & $168(8.0)$ & & \\
\hline Discharge outcome & & & & & & & & & $<0.001$ & 0.077 \\
\hline Treated & $812(86.5)$ & $\begin{array}{l}539 \\
(84.1)\end{array}$ & $\begin{array}{l}4817 \\
(78.5)\end{array}$ & $\begin{array}{l}1242 \\
(82.1)\end{array}$ & $\begin{array}{l}3824 \\
(83.8)\end{array}$ & $639(82.6)$ & $\begin{array}{l}373 \\
(90.8)\end{array}$ & $1779(85.2)$ & & \\
\hline Unchanged or worsened & $35(3.7)$ & $34(5.3)$ & $555(9.0)$ & $95(6.3)$ & $239(5.2)$ & $46(5.9)$ & $15(3.6)$ & $105(5.0)$ & & \\
\hline Death & $69(7.3)$ & $68(10.6)$ & $568(9.3)$ & $153(10.1)$ & $399(8.7)$ & $85(11.0)$ & $23(5.6)$ & $140(6.7)$ & & \\
\hline Other & $23(2.4)$ & $0(0.0)$ & $198(3.2)$ & $22(1.5)$ & $99(2.2)$ & $4(0.5)$ & $0(0.0)$ & $64(3.1)$ & & \\
\hline Length of stay & & & & & & & & & $<0.001$ & 0.044 \\
\hline 2-17 days & $297(31.6)$ & $\begin{array}{l}134 \\
(20.9)\end{array}$ & $\begin{array}{l}1650 \\
(26.9)\end{array}$ & $358(23.7)$ & $\begin{array}{l}1380 \\
(30.3)\end{array}$ & $205(26.5)$ & $\begin{array}{l}119 \\
(29.0)\end{array}$ & $611(29.3)$ & & \\
\hline 18-30 days & $233(24.8)$ & $\begin{array}{l}150 \\
(23.4)\end{array}$ & $\begin{array}{l}1452 \\
(23.7)\end{array}$ & $397(26.3)$ & $\begin{array}{l}1217 \\
(26.7)\end{array}$ & $220(25.8)$ & $\begin{array}{l}125 \\
(30.4)\end{array}$ & $556(26.6)$ & & \\
\hline $31-54$ days & $189(20.1)$ & $\begin{array}{l}173 \\
(27.0)\end{array}$ & $\begin{array}{l}1539 \\
(25.1)\end{array}$ & $409(27.1)$ & $\begin{array}{l}1093 \\
(24.0)\end{array}$ & 221 (28.6) & $87(21.1)$ & $500(23.9)$ & & \\
\hline 55 days and over & $220(23.4)$ & $\begin{array}{l}184 \\
(28.7)\end{array}$ & $\begin{array}{l}1497 \\
(24.4)\end{array}$ & $348(23.0)$ & 871 (19.1) & $148(19.1)$ & $80(19.5)$ & $421(20.2)$ & & \\
\hline $\begin{array}{l}\text { Consultation-Liaison Psychiatry per patient } \\
\text { (mean (sd)) }\end{array}$ & $2.95(2.83)$ & $\begin{array}{l}2.93 \\
(2.63)\end{array}$ & $\begin{array}{l}2.98 \\
(2.89)\end{array}$ & $\begin{array}{l}2.76 \\
(2.46)\end{array}$ & $\begin{array}{l}2.64 \\
(2.54)\end{array}$ & $\begin{array}{l}2.59 \\
(2.25)\end{array}$ & $\begin{array}{l}2.25 \\
(1.90)\end{array}$ & $2.78(3.22)$ & $<0.001$ & \\
\hline
\end{tabular}

understand how to make for future improvements to the healthcare system.

After the introduction of CLP services in 2012, the provision of CLP was consistently increased (Table 1), implying the recognition of the need for CLP services in medical and surgical patients. Also, almost $70 \%$ of patients we studied who received CLP services were over the age of 65 in 2016, which was much higher than in recent studies in a Canadian setting (roughly $42 \%$ from two academic tertiary care hospitals) [27] and an Italian setting (mean and SD age was $57.9 \pm 19.4$ from one general hospital) which were in line with other reports from Europe in terms of demographic data (about 41\%) [28]. We speculated that this is due to the difference in the aging ratio of 
Table 5 Disease classification of patients by region (2016)

\begin{tabular}{|c|c|c|c|c|c|c|c|c|c|c|}
\hline Variables & Hokkaido & Tohoku & Kanto & Chubu & Kinki & Chugoku & Shikoku & $\begin{array}{l}\text { Kyushu- } \\
\text { Okinawa }\end{array}$ & $\begin{array}{l}p \\
\text { value }\end{array}$ & $\begin{array}{l}\text { Cramer's } \\
\text { V }\end{array}$ \\
\hline $\mathrm{N}$ & 939 & 641 & 6138 & 1512 & 4561 & 774 & 411 & 2088 & & \\
\hline Disease classification & & & & & & & & & $<0.001$ & 0.078 \\
\hline 1. Certain infectious and parasitic diseases & $33(3.5)$ & $18(2.8)$ & $\begin{array}{l}230 \\
(3.7)\end{array}$ & $\begin{array}{l}46 \\
(3.0)\end{array}$ & $\begin{array}{l}157 \\
(3.4)\end{array}$ & $16(2.1)$ & $10(2.4)$ & $70(3.4)$ & & \\
\hline 2. Neoplasms & $240(25.6)$ & $\begin{array}{l}104 \\
(16.2)\end{array}$ & $\begin{array}{l}1393 \\
(22.7)\end{array}$ & $\begin{array}{l}302 \\
(20.0)\end{array}$ & $\begin{array}{l}1060 \\
(23.2)\end{array}$ & $234(30.2)$ & $59(4.4)$ & $\begin{array}{l}514 \\
(24.6)\end{array}$ & & \\
\hline $\begin{array}{l}\text { 3. Diseases of the blood and blood-forming or- } \\
\text { gans and certain disorders involving the immune } \\
\text { mechanism }\end{array}$ & $19(2.0)$ & $9(1.4)$ & $\begin{array}{l}84 \\
(1.4)\end{array}$ & $\begin{array}{l}15 \\
(1.0)\end{array}$ & $\begin{array}{l}68 \\
(1.5)\end{array}$ & $7(0.9)$ & $4(1.0)$ & $20(1.0)$ & & \\
\hline 4. Endocrine, nutritional, and metabolic diseases & $30(3.2)$ & $18(2.8)$ & $\begin{array}{l}216 \\
(3.5)\end{array}$ & $\begin{array}{l}59 \\
(3.9)\end{array}$ & $\begin{array}{l}160 \\
(3.5)\end{array}$ & $17(2.2)$ & $12(2.9)$ & $84(4.0)$ & & \\
\hline 5. Mental and behavioral disorders & $13(1.4)$ & $11(1.7)$ & $\begin{array}{l}107 \\
(1.7)\end{array}$ & $\begin{array}{l}35 \\
(2.3)\end{array}$ & $\begin{array}{l}72 \\
(1.6)\end{array}$ & $23(3.0)$ & $8(1.9)$ & $59(2.8)$ & & \\
\hline 6. Diseases of the nervous system & $44(4.7)$ & $13(2.0)$ & $\begin{array}{l}238 \\
(3.9)\end{array}$ & $\begin{array}{l}52 \\
(3.4)\end{array}$ & $\begin{array}{l}133 \\
(2.9)\end{array}$ & $34(4.4)$ & $12(2.9)$ & $83(4.0)$ & & \\
\hline 7. Diseases of the eye and adnexa & $10(1.1)$ & $3(0.5)$ & $\begin{array}{l}20 \\
(0.3)\end{array}$ & $\begin{array}{l}14 \\
(0.9)\end{array}$ & $\begin{array}{l}8 \\
(0.2)\end{array}$ & $3(0.4)$ & $0(0.0)$ & $13(0.6)$ & & \\
\hline 8. Diseases of the ear and mastoid process & $2(0.2)$ & $3(0.5)$ & $\begin{array}{l}26 \\
(0.4)\end{array}$ & $3(0.2)$ & $\begin{array}{l}2 \\
(0.0)\end{array}$ & $0(0.0)$ & $0(0.0)$ & $3(0.1)$ & & \\
\hline 9. Diseases of the circulatory system & $191(20.3)$ & $\begin{array}{l}125 \\
(19.5)\end{array}$ & $\begin{array}{l}1219 \\
(19.9)\end{array}$ & $\begin{array}{l}230 \\
(15.2)\end{array}$ & $\begin{array}{l}710 \\
(15.6)\end{array}$ & $119(15.4)$ & $67(16.3)$ & $190(9.1)$ & & \\
\hline 10. Diseases of the respiratory system & $58(6.2)$ & $\begin{array}{l}72 \\
(11.2)\end{array}$ & $\begin{array}{l}502 \\
(8.2)\end{array}$ & $\begin{array}{l}185 \\
(12.2)\end{array}$ & $\begin{array}{l}426 \\
(9.3)\end{array}$ & $59(7.6)$ & $78(19.0)$ & $162(7.8)$ & & \\
\hline 11. Diseases of the digestive system & $72(7.7)$ & $\begin{array}{l}70 \\
(10.9)\end{array}$ & $\begin{array}{l}557 \\
(9.1)\end{array}$ & $\begin{array}{l}147 \\
(9.7)\end{array}$ & $\begin{array}{l}480 \\
(10.5)\end{array}$ & $81(10.5)$ & $37(9.0)$ & $222(0.6)$ & & \\
\hline 12. Diseases of the skin and subcutaneous tissue & $12(1.3)$ & $8(1.2)$ & $\begin{array}{l}83 \\
(1.4)\end{array}$ & $\begin{array}{l}33 \\
(2.2)\end{array}$ & $\begin{array}{l}64 \\
(1.4)\end{array}$ & $19(2.5)$ & $4(1.0)$ & $38(1.8)$ & & \\
\hline $\begin{array}{l}\text { 13. Diseases of the musculoskeletal system and } \\
\text { connective tissue }\end{array}$ & $56(6.0)$ & $27(4.2)$ & $\begin{array}{l}439 \\
(7.2)\end{array}$ & $\begin{array}{l}72 \\
(4.8)\end{array}$ & $\begin{array}{l}338 \\
(7.4)\end{array}$ & $29(3.7)$ & $16(3.9)$ & $108(5.2)$ & & \\
\hline 14. Diseases of the genitourinary system & $41(4.4)$ & $28(4.4)$ & $\begin{array}{l}229 \\
(3.7)\end{array}$ & $\begin{array}{l}77 \\
(5.1)\end{array}$ & $\begin{array}{l}217 \\
(4.8)\end{array}$ & $24(3.1)$ & $13(3.2)$ & $82(3.9)$ & & \\
\hline 15. Pregnancy, childbirth, and the puerperium & $15(1.6)$ & $8(1.2)$ & $\begin{array}{l}67 \\
(1.1)\end{array}$ & $\begin{array}{l}18 \\
(1.2)\end{array}$ & $\begin{array}{l}40 \\
(0.9)\end{array}$ & $2(0.3)$ & $1(0.2)$ & $62(3.0)$ & & \\
\hline $\begin{array}{l}\text { 17. Congenital malformations, deformations, and } \\
\text { chromosomal abnormalities }\end{array}$ & $3(0.3)$ & $1(0.2)$ & $\begin{array}{l}22 \\
(0.4)\end{array}$ & $2(0.1)$ & $\begin{array}{l}4 \\
(0.1)\end{array}$ & $4(0.5)$ & $2(0.5)$ & $2(0.1)$ & & \\
\hline $\begin{array}{l}\text { 18. Symptoms, signs, and abnormal clinical and } \\
\text { laboratory findings, not elsewhere classified }\end{array}$ & $0(0.0)$ & $0(0.0)$ & $2(0.0)$ & $0(0.0)$ & $\begin{array}{l}2 \\
(0.0)\end{array}$ & $0(0.0)$ & $1(0.2)$ & $1(0.0)$ & & \\
\hline $\begin{array}{l}\text { 19. Injury, poisoning, and certain other } \\
\text { consequences of external causes }\end{array}$ & $100(10.6)$ & $\begin{array}{l}123 \\
(19.2)\end{array}$ & $\begin{array}{l}704 \\
(11.5)\end{array}$ & $\begin{array}{l}222 \\
(14.7)\end{array}$ & $\begin{array}{l}620 \\
(13.6)\end{array}$ & $10313.3)$ & $87(21.2)$ & $\begin{array}{l}374 \\
(17.9)\end{array}$ & & \\
\hline $\begin{array}{l}\text { 21. Factors influencing health status and contact } \\
\text { with health services }\end{array}$ & $0(0.0)$ & $0(0.0)$ & $0(0.0)$ & $0(0.0)$ & $\begin{array}{l}0 \\
(0.0)\end{array}$ & $0(0.0)$ & $0(0.0)$ & $1(0.0)$ & & \\
\hline
\end{tabular}

the study population, criteria for referral, priority/availability for CLP referral, and the healthcare system. Our results also showed that about $70 \%$ of CLP services were provided to patients whose admittance was unplanned or who were admitted due to an urgent condition. This is partly because such patients may not have been prepared for, or may be especially agitated about, their health problems compared with planned admission patients.

While data regarding discharge settings and outcomes were usually unavailable internationally, it was reasonable that about three out of every 10 patients who received CLP were transferred to other hospitals (Table 1), which is much higher than the $5.8-7.5 \%$ overall average of acute - /mixed-care inpatients in a Japanese setting [29]. We speculated that some of the patients with psychiatric comorbidities were transferred to psychiatric hospitals (detailed data about discharge settings were not available). It was surprising that about $9 \%$ of patients who received CLP services were discharged as dead (Table 1), which was also much higher than the overall average of $1.7-3.3 \%$ 
Table 6 Multivariate linear regression analysis results for number of consultations per CLP patient

\begin{tabular}{|c|c|c|c|}
\hline Variable & $\beta$ & $p$ value & VIF \\
\hline Region (reference: Hokkaido) & & & 1.012 \\
\hline Tohoku & -0.220 & 0.034 & \\
\hline Kanto & -0.075 & 0.192 & \\
\hline Chubu & -0.071 & 0.279 & \\
\hline Kinki & 0.009 & 0.882 & \\
\hline Chugoku & -0.160 & 0.026 & \\
\hline Shikoku & -0.555 & $<0.001$ & \\
\hline Kyusyu-Okinawa & -0.121 & 0.055 & \\
\hline Age group (reference: $85+$ ) & & & 1.027 \\
\hline $0-29$ & 0.410 & $<0.001$ & \\
\hline $30-49$ & 0.263 & $<0.001$ & \\
\hline $50-64$ & 0.256 & $<0.001$ & \\
\hline $65-74$ & 0.144 & $<0.001$ & \\
\hline $75-84$ & 0.016 & $<0.001$ & \\
\hline Sex (reference: Male) & & & 1.030 \\
\hline Female & 0.048 & 0.011 & \\
\hline Admission setting (reference; planed) & & & 1.154 \\
\hline Unplanned & -0.021 & 0.044 & \\
\hline Disease classification (reference: 9.Diseases of the circulatory system) & & & 1.014 \\
\hline 1.Certain infectious and parasitic diseases & 0.315 & $<0.001$ & \\
\hline 2.Neoplasms & 0.098 & 0.018 & \\
\hline 3.Diseases of the blood and blood-forming organs and certain disorders involving the immune mechanism & 0.298 & 0.004 & \\
\hline 4.Endocrine, nutritional, and metabolic diseases & -0.025 & 0.722 & \\
\hline 5.Mental and behavioral disorders & -1.016 & $<0.001$ & \\
\hline 6.Diseases of the nervous system & 0.076 & 0.283 & \\
\hline 7.Diseases of the eye and adnexa & -0.127 & 0.498 & \\
\hline 8.Diseases of the ear and mastoid process & -0.287 & 0.212 & \\
\hline 10.Diseases of the respiratory system & 0.133 & 0.010 & \\
\hline 11.Diseases of the digestive system & 0.088 & 0.079 & \\
\hline 12.Diseases of the skin and subcutaneous tissue & 0.118 & 0.225 & \\
\hline 13.Diseases of the musculoskeletal system and connective tissue & 0.290 & $<0.001$ & \\
\hline 14.Diseases of the genitourinary system & -0.007 & 0.912 & \\
\hline 15.Pregnancy, childbirth, and the puerperium & -0.295 & 0.012 & \\
\hline 17.Congenital malformations, deformations, and chromosomal abnormalities & -0.121 & 0.622 & \\
\hline 18.Symptoms, signs, and abnormal clinical and laboratory findings, not elsewhere classified & 0.053 & 0.927 & \\
\hline 19.Injury, poisoning, and certain other consequences of external causes & 0.125 & 0.006 & \\
\hline 21.Factors influencing health status and contact with health services & -0.392 & 0.880 & \\
\hline Fiscal year (reference; 2012) & & & 1.010 \\
\hline 2013 & 0.226 & $<0.001$ & \\
\hline 2014 & 0.235 & $<0.001$ & \\
\hline 2015 & 0.233 & $<0.001$ & \\
\hline 2016 & 0.039 & 0.398 & \\
\hline Length of Stay (reference; 2-17 days) & & & 1.015 \\
\hline 18-30 days & 0.111 & $<0.001$ & \\
\hline
\end{tabular}


Table 6 Multivariate linear regression analysis results for number of consultations per CLP patient (Continued)

\begin{tabular}{lll}
\hline Variable & $\boldsymbol{\beta}$ & $\boldsymbol{p}$ value \\
\hline $31-54$ days & 0.246 & $<0.001$ \\
55 days and over & 0.587 & $<0.001$ \\
Adjusted R-squared & 0.274 \\
\hline
\end{tabular}

VIF Variance Inflation Factor

[30]. We also speculated that some CLP services were provided for severe patients who needed psychiatric support for improving their mental condition as a part of end-oflife care. However, further studies are required to address this issue due to data unavailability.

It was reasonable that more than one-fifth of CLP services were provided to the cancer patients, considering both the number of cancer inpatients (13.4\% in general hospitals) [31] and that approximately $29-43 \%$ of these patients fulfilled the diagnostic criteria for having a psychiatric disorder [32, 33] (Table 2). However, in terms of international comparisons of CLP data, it is not easy to compare in detail. For example, few data were available in the basic disease classifications of the study cohorts. Even if data were shown, as in the Canadian study [27], it may not be easy to compare with our data due to the absence of consensus in disease classifications for CLP cases. Another example is that our data pertaining to the reasons for CLP referrals (psychiatric diagnosis) are not available, as they were for a previous study [27, 34], because the DPC database was not designed for specific studies but various research fields. Further efforts for international collaborative research will help improve the quality of available evidence.

Almost $70 \%$ of patients who received CLP services used in-hospital psychotherapy; the rests did not use in-hospital psychotherapy (Appendix). This is partly because some CLP services were provided to patients with postoperative delirium which usually disappeared in a short period (i.e., a week), who usually did not need in-hospital psychotherapy. Although the distribution of the number of provided in-hospital psychotherapy sessions was right-skewed, there was another peak in "six and over" during hospitalization. These patients would be those with severe psychiatric conditions or longer lengths of stay. Another possibility is that there was a lack of in-hospital psychiatry in some cases, especially in hospitals where psychiatric healthcare resources are scarce. This is one of the further questions to be addressed.

CLP in Japan started from selected prefectures and gradually spread throughout Japan; however, there are still 14 prefectures where provided no
CLP services with their own in 2016 (Fig. 1). In addition, there is a variation in providing CLP services even in the regions (Table 3 ). Although 5 years had passed from the introduction of CLP, there is still geographical disparity of CLP services, which needs to be improved. It is similar in the United Kingdom, where studies identified widespread availability of liaison psychiatry services in acute care hospitals [35].

The results of the test of independence showed the association between regions and basic variables regarding clinical features (Tables 4 and 5). Although Chi-square test did not provide the strength of the association, the results indicated that the provision of CLP differs among regions. Indeed, there were variations in the proportion of CLP such as for older patients aged 75 and over (11.8 to $30.0 \%$ ), for planned admission setting (15.6 to $47.1 \%$ ), and for disease classification (e.g., neoplasm; 4.4 to $30.2 \%)$. There results also implied the regional difference in the needs of CLP services, in psychiatric healthcare resources for CLP, and in demand-supply balance in CLP. Investigation in the current/future needs of CLPs and enhancing/ expanding the delivery system of CLPs would be considerable.

The results of the multivariate linear regression analysis showed that Tohoku, Shikoku, and Chugoku showed a significant negative correlation with the number of consultations per CLP patient, when compared with Hokkaido, after adjusting for covariates. The results also indicated that several covariates were associated with the number of consultations per CLP patient; for example, i) female patients and younger patients may need more CLP care during hospitalization, ii) the number of consultations per CLP patient may differ among types of diseases, and iii) some patients with longer length of stay may need more CLP care due to severe psychiatric disorders. However, the model explained only $27.4 \%$ of the variance in dependent variable, and other factors contribute to the heterogeneity. This implies not only geographic disparity but also unmeasured confounding factors, such as patients' psychiatric severity, reason for CLP referral, detailed interventions in CLP, timing of CLP, and psychiatric 
healthcare resources at each hospital. Because CLP is provided to the medical or surgical (somatic) patients, disease category "Mental and behavioral disorders" (most resource-consuming diagnosis) was negatively associated with the number of consultations per CLP patient.

Unfortunately, data regarding CLP in Japan is scarce; even it is not clear how many patients need CLP. It is important to construct database which enables CLP researches. It is not clear whether the impact of CLP differs according to the psychiatric severity or patients' other clinical background. It is also not clear whether regional psychiatric healthcare resources are associated with the need of CLP or not. The database needs to include patients who need CLP care, regardless of whether they receive CLP, as it could help assess the impact of CLP services on patients' outcome, such as readmission, patient-reported outcome, cost, and length of stay. Inclusion of variables regarding types of CLP intervention, including patients' severity, types of psychiatric disorder, and other essential information, is also required for epidemiological investigation. Further efforts for improving geographic disparity are needed for achieving efficient care in CLP services for those who needed care. Further researches for assessing the impact of CLP on outcome, costeffectiveness, and accessibility are also attractive.

This study has major strengths: it is the largest reported study on this subject in terms of patient numbers in a Japanese setting based on a national administrative database. According to the National Database Open Data, the analysis covered more than 92\% of the CLPs in Japan [36]. Further, to our knowledge, this study was the first report which reveals fundamental information of CLP services and geographic disparity in CLP services in Japanese setting which were essential for enhancing the quality of life of patients and improving efficiency in the healthcare delivery system. Thus, our results could inform future interventions to improve medical services and the provision of healthcare.

Several limitations of the present study must be considered. First, this was a retrospective observational study based on an administrative database (DPC). The database covers more than 93\% of CLP services conducted across Japan; however, a few hospitals do not participate in the DPC/PDPS system and the exclusion of these hospitals may have introduced an element of sampling bias. The DPC database did not include information whether CLP planning adapted to the needs of patients/hospital/ wards are not available. Meanwhile, the CLP team are required to organize treatment plan, explain the plan to the patients, assess the symptoms, and adjusting psychiatric care after discharge. The team also required to write what they do as the team to (electronic) medical record, which are sometimes reviewed by the public agency. In addition, hospitals are required to satisfy facility standards for CLP team (experienced psychiatric staff) to receive fees from providing CLP services. Hence, we speculated that most CLP services adapted to the needs of the patients, however, it is hard to validate this adaption without detailed information which is unavailable in the present study.

Second, data pertaining to several important variables are not available in the DPC database. Therefore, factors such as the difference in psychiatric severity, psychiatric diagnosis before and after CLP, reason for CLP referral, timing of CLP, who provides CLP (doctors or nurses), detailed interventions in CLPs, degree of psychiatrists' proficiency, and to what extend do the hospitals, psychiatrists and population accept CLP were not included in the analysis. Detailed information regarding psychotherapy was not included neither. We have defined variables based on existing data in the DPC database. Because the DPC database is administrative, we could not add new variables to it for our research purpose. We also could not know number of psychiatrists, preference for CLP in each hospital, and criteria for CLP in each hospital due to the anonymized dataset. In addition, we could not define patients who needs to be received CLP due to the data unavailability. A validation study that defines patients who need CLP is strongly required for assessing factors associated with CLP referral.

Third, the present study did not analyze patient outcomes. Although previous researches had reported the benefit of CLP services [13-17], further outcome studies based on a DPC database would be preferred.

\section{Conclusions}

Data regarding CLP services at the national level had not been analyzed and organized in a way that makes it usable for patients, health care providers, or policy administrators. Our present study revealed the fundamental information and geographical disparity in CLP services in Japan. These results can inform hospital administrators and health service providers improvement the equity of the provision, efficiency of service, and policies relating to healthcare involving CLP. Further research is also needed comparing outcomes of qualifying patients who receive CLP with those who qualify but do not receive these coordinated services and to compare availability, insurance coverage, and utilization of CLP in other countries. 


\section{Appendix}

Table 7 Provision of in-hospital psychotherapy in the study cohort

\begin{tabular}{|c|c|c|c|c|c|c|c|}
\hline \multirow[t]{2}{*}{ Variables } & \multicolumn{5}{|c|}{ Fiscal year } & \multirow{2}{*}{$\begin{array}{l}\text { Proportion } \\
\text { of patients } \\
\text { (n) in } 2012\end{array}$} & \multirow{2}{*}{$\begin{array}{l}\text { Proportion } \\
\text { of patients } \\
\text { (n) in } 2016\end{array}$} \\
\hline & 2012 & 2013 & 2014 & 2015 & 2016 & & \\
\hline \multicolumn{8}{|c|}{ Psychotherapy (in-hospital) } \\
\hline 0 & 941 & 1397 & 2802 & 3629 & 5445 & $23.6 \%$ & $31.9 \%$ \\
\hline 1 & 829 & 1305 & 1721 & 2317 & 3331 & $20.8 \%$ & $19.5 \%$ \\
\hline 2 & 551 & 793 & 1032 & 1586 & 2328 & $13.8 \%$ & $13.6 \%$ \\
\hline 3 & 418 & 497 & 710 & 1036 & 1670 & $10.5 \%$ & $9.8 \%$ \\
\hline 4 & 297 & 343 & 492 & 705 & 1129 & $7.4 \%$ & $6.6 \%$ \\
\hline 5 & 209 & 225 & 375 & 509 & 791 & $5.2 \%$ & $4.6 \%$ \\
\hline $6+$ & 744 & 792 & 1226 & 1626 & 2370 & $18.7 \%$ & $13.9 \%$ \\
\hline
\end{tabular}

\section{Abbreviations}

CLP: Consultation-liaison psychiatry; DPC: Diagnosis Procedure Combination; DPC/PDPS: Diagnosis Procedure Combination per-diem payment system, ICD: International Classification of Diseases; IQR: Interquartile Range; OECD: Organization for Economic Cooperation and Development

\section{Supplementary Information}

The online version contains supplementary material available at https://doi. org/10.1186/s12888-021-03241-y.

Additional file 1. Post hoc analysis of patient charactereistics by region.

\section{Acknowledgements}

We wish to extend our thanks for the cooperation we received from everyone involved at the institutions in the National Center of Child Health and Development and the Tokyo Medical and Dental University.

\section{Authors' contributions}

DS participated in study design, analysis and interpretation of data, drafting the article, and revising the article for intellectual content. NI, HT and KMS participated in study design, interpretation of data, drafting the article, and revising the article for intellectual content. KFj and KFs participated in study design, interpretation of data, and revising the article for intellectual content. All authors read and approved the final manuscript.

\section{Funding}

This study was supported by a Grant-in-Aid for Research on Policy Planning and Evaluation from the Ministry of Health, Labour and Welfare, Japan ( $\mathrm{H} 29-$ Seisaku-Shitei-009), a Grant-in-Aid for Young Scientists (B) from the Japan Society for the Promotion of Science (JSPS KAKENHI, 16 K19284). The Foundation has had no influence in the design of the study, data collection, analysis or interpretation of data, publication of results or writing this manuscript.

\section{Availability of data and materials}

The data availability is not applicable due to an ethical restriction. However, data will be made available by the DPC research group for researchers who meet the criteria for access to these confidential data. Request to access the data should be submitted to the corresponding author.

\section{Declarations}

\section{Ethics approval and consent to participate}

This study was approved by the Institutional Review Board at the Tokyo Medical and Dental University and the National Center for Child Health and Development. The board waived off the requirement for patient informed consent because of the anonymous nature of the data. The approval to access the administrative database (anonymized database) maintained by the DPC research group, located in Japan requires the data to be treated as confidential with protected and secure access. For this reason, the data cannot be shared publicly. However, processed data which we used in this study will be available for researchers who meet the criteria for data access. Request to access data should be submitted to corresponding author. We had permission for accessing a partial dataset (for this research purpose) from the DPC research group.

\section{Consent for publication}

Not applicable.

\section{Competing interests}

The authors declare that they have no competing interests.

\section{Author details}

${ }^{1}$ Department of Information Technology and Management, The National Center of Child Health and Development, Tokyo, Japan. ${ }^{2}$ Department of Health Policy and Informatics, Tokyo Medical and Dental University Graduate School, 1-5-45 Yushima, Bunkyo-ku, Tokyo 1138519, Japan. ${ }^{3}$ Department of Mental Health Policy and Evaluation, National Institute of Mental Health, The National Center of Neurology and Psychiatry, Tokyo, Japan. ${ }^{4}$ Institute for Global Health Policy Research, The National Center for Global Health and Medicine, Tokyo, Japan. ${ }^{5}$ Department of Health Administration and Policy, Tohoku University, Sendai, Japan.

Received: 3 June 2020 Accepted: 27 April 2021

Published online: 05 May 2021

References

1. OECD. Health at a Glance 2019: OECD Indicators. 2019. OECD publishing, Paris. doi: https://doi.org/10.1787/4dd50c09-en.

2. OECD. OECD Reviews of Health Care Quality: Japan 2015 (Raising Standards). 2015. https://www.oecd.org/publications/oecd-reviews-of-hea Ith-care-quality-japan-2015-9789264225817-en.htm

3. Levenson $J$, Hamer RM, Rossiter LF. Relation of psychopathology in general medical inpatients to use and cost of services. Am J Psychiatry. 1990; 147(11):1498-503. https://doi.org/10.1176/ajp.147.11.14984.

4. Furlanetto LM, da Silva RV, Bueno JR. The impact of psychiatric comorbidity on length of stay of medical inpatients. Gen Hosp Psychiatry. 2003;25(1):149. https://doi.org/10.1016/s0163-8343(02)00236-0.

5. Koopmans GT, Donker MC, Rutten FH. Length of hospital stay and health services use of medical inpatients with comorbid noncognitive mental disorders: a review of the literature. Gen Hosp Psychiatr. 2005;27:44-56. https://doi.org/10.1016/j.genhosppsych.2004.09.008.

6. Bourgeois JA, Kremen WS, Servis ME, Wegelin JA, Hales RE. The impact of psychiatric diagnosis on length of stay in a university medical center in the managed care era. Psychosomatics. 2005;46(5):431-9. https://doi.org/10.11 76/appi.psy.46.5.431.

7. Abrams TE, Vaughan-Sarrazin M, Rosenthal GE. Influence of psychiatric comorbidity on surgical mortality. Arch Surg. 2010;145(2):947-53. https://doi. org/10.1016/j.arth.2014.08.034. 
8. Davies SJC, Iwajomo T, de Oliveira C, Versloot J, Reid RJ, Kurdyak P. The impact of psychiatric and medical comorbidity on the risk of mortality: a population-based analysis. Psychol Med. 2019;51(2):1-9. https://doi.org/10.1 017/S003329171900326X.

9. Hanrahan NP, Bressi S, Marcus SC, Solomon P. Examining the impact of comorbid serious mental illness on rehospitalization among medical and surgical inpatients. Gen Hosp Psychiatry. 2016;42:36-40. https://doi.org/10.1 016/j.genhosppsych.2016.06.002.

10. Lipowski ZJ. Reviewof consultation psychiatry and psychosomatic medicine. I General principles. Psychosom Med. 1967;29(2):153-71. https://doi.org/10.1 097/00006842-196703000-00007.

11. Lipowski ZJ. Review of consultation psychiatry and psychosomatic medicine. II Clinical aspects. Psychosom Med. 1967;29(3):201-24. https://doi. org/10.1097/00006842-196705000-00001.

12. Lipowski Z. Consultation-liaison psychiatry in a general hospital. Compr Psychiatry. 1971;12(5):461-5. https://doi.org/10.1016/0010-440x(71)90086-1.

13. de Jonge $\mathrm{P}$, Latour $\mathrm{CH}$, Huyse FJ. Implementing psychiatric interventions on a medical ward: effects on patients' quality of life and length of hospital stay. Psychosom Med. 2003;65(6):997-1002. https://doi.org/10.1097/01.psy. 0000097332.77685.c8.

14. Ormont MA, Weisman HW, Heller SS, Najara JE, Shindledecker RD. The timing of psychiatric consultation requests. Utilization, liaison, and diagnostic considerations. Psychosomatics. 1997;38(1):38-44. https://doi. org/10.1016/S0033-3182(97)71502-0

15. Kishi $Y$, Meller WH, Kathol RG, Swigart SE. Factors affecting the relationship between the timing of psychiatric consultation and general hospital length of stay. Psychosomatics. 2004;45(6):470-6. https://doi.org/10.1176/appi.psy.4 5.6.470.

16. Desan PH, Zimbrean PC, Weinstein AJ, Bozzo JE, Sledge WH. Proactive psychiatric consultation services reduce length of stay for admissions to an inpatient medical team. Psychosomatics. 2011;52(6):513-20. https://doi.org/1 0.1016/j.psym.2011.06.002.

17. Aoki T, Sato T, Hosaka T. Role of consultation-liaison psychiatry toward shortening of length of stay for medically ill patients with depression. Int Psychiatry Clin Pract. 2004;8(2):71-6. https://doi.org/10.1080/1365150031 0004957.

18. Grassi L, Mitchell AJ, Otani M, Caruso R, Nanni MG, Hachizuka M, et al. Consultation-liaison psychiatry in the general hospital: the experience of UK Italy, and Japan. Curr Psychiatry Rep. 2015;17(6):44. https://doi.org/10.1007/ s11920-015-0581-1.

19. The Japanese Society of General Hospital Psychiatry, Liaison Multidisciplinary Committee. Clinical guide for consultation-liaison psychiatry team. 2019. Seiwa-Shoten. [Japanese].

20. Kishi Y, Kurosawa H. Consultation liaison psychiatry and emergency medicine in Japan. JJAAM. 2010;21:147-58.

21. Yamada K, Hosoda M, Nakashima S, Furuta K, Awata S. Psychiatric diagnosis in the elderly referred to a consultation-liaison psychiatry service in a general geriatric hospital in Japan. Geriatr Gerontol Int. 2012;12(2):304-9. https://doi.org/10.1111/j.1447-0594.2011.00771.x.

22. Ogawa A, Nouno J, Shirai Y, Shibayama O, Kondo K, Yokoo M, et al. Availability of psychiatric consultation-liaison services as an integral component of palliative care programs at Japanese cancer hospitals. Jpn J Clin Oncol. 2012;42(1):42-52. https://doi.org/10.1093/jjco/hyr174.

23. Yamana $H$, Moriwaki $M$, Horiguchi $H$, Kodan M, Fushimi $K$, Yasunaga $H$. Validity of diagnoses, procedures, and laboratory data in Japanese administrative data. J Epidemiol. 2017;27(10):476-82. https://doi.org/10.1016/ j.je.2016.09.009.

24. Shinjo D, Tachimori H, Maruyama-Sakurai K, Ohnuma T, Fujimori K, Fushimi K. Risk factors for early unplanned readmission in patients with bipolar disorder: a retrospective observational study. Gen Hosp Psychiatry. 2019;58: 51-8. https://doi.org/10.1016/j.genhosppsych.2019.03.003.

25. Ministry of Internal Affairs and Communications. Summary table of the Population Estimates in 2016, Table 11. Population by Age (3 Groups) and Sex for Prefectures. 2017. https://www.stat.go.jp/data/jinsui/2016np/index. html

26. Wierdsma Al, Poodt HD, Mulder CL. Effects of community-care networks on psychiatric emergency contacts, hospitalisation and involuntary admission. J Epidemiol Community Health. 2007:61(7):613-8. https://doi.org/10.1136/ jech.2005.044974.

27. Zhou C, Rajaratnam T, Abbey S, Hawa R, Sheehan K, Sockalingam S. Measuring quality of care in consultation liaison psychiatry: outcomes from two Canadian hospitals. Gen Hosp Psychiatry. 2018;54:54-6. https://doi.org/1 0.1016/j.genhosppsych.2018.01.010

28. De Giorgio G, Quartesan R, Sciarma T, Giulietti M, Piazzoli A, Scarponi L, et al. Consultation-liaison psychiatry-from theory to clinical practice: an observational study in a general hospital. BMC Res Notes. 2015;8(1):475. https://doi.org/10.1186/s13104-015-1375-6.

29. Ministry of Health, Labour and Welfare. Summary table of the Diagnosis Procedure Combination database in 2016, (8) Admission and discharge setting. 2018.

30. Ministry of Health, Labour and Welfare. Summary table of the Diagnosis Procedure Combination database in 2016, (9) Discharge outcome. 2018. https://www.mhlw.go.jp/file/06-Seisakujouhou-12400000-Hokenkyoku/00001 88034.pdf

31. Ministry of Health, Labour and Welfare. Summary table of the Patient Survey in 2017, Appendix 8. Estimated number of inpatients according to disease classification. 2019. https://www.mhlw.go.jp/toukei/saikin/hw/kanja/1 Osyoubyo/.

32. Zabora J, BrintzenhofeSzoc K, Curbow B, Hooker C, Piantadosi S. The prevalence of psychological distress by cancer site. Psychooncology. 2001; 10(1):19-28. https://doi.org/10.1002/1099-1611(200101/02)10:1<19::aidpon501>3.0.co;2-6.

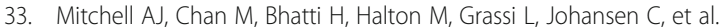
Prevalence of depression, anxiety, and adjustment disorder in oncological, haematological, and palliative-care settings: a meta-analysis of 94 interviewbased studies. Lancet Oncol. 2011;12(2):160-74. https://doi.org/10.1016/S14 70-2045(11)70002-X

34. Lucke C, Gschossmann JM, Schmidt A, Gschossmann J, Lam AP, Schneider $C E$, et al. A comparison of two psychiatric service approaches: findings from the consultation vs. Liaison Psychiatry-Study BMC Psychiatry. 2017;17(1):8. https://doi.org/10.1186/s12888-016-1171-4.

35. Walker A, Barrett JR, Lee W, West RM, Guthrie E, Trigwell P, et al. Organisation and delivery of liaison psychiatry services in general hospitals in England: results of a national survey. BMJ Open. 2018;8(8):e023091. https://doi.org/10.1136/bmjopen-2018-023091.

36. Ministry of Health, Labour and Welfare. Summary table of the 3rd NDB Open Data Japan, (A.Specific hospitalization fee, addition). 2018. https:// www.mhlw.go.jp/stf/seisakunitsuite/bunya/0000177221 00002.htm

\section{Publisher's Note}

Springer Nature remains neutral with regard to jurisdictional claims in published maps and institutional affiliations.

Ready to submit your research? Choose BMC and benefit from:

- fast, convenient online submission

- thorough peer review by experienced researchers in your field

- rapid publication on acceptance

- support for research data, including large and complex data types

- gold Open Access which fosters wider collaboration and increased citations

- maximum visibility for your research: over $100 \mathrm{M}$ website views per year

At BMC, research is always in progress.

Learn more biomedcentral.com/submission 